\title{
EFEKTIVITAS BERKUMUR LARUTAN EKSTRAK ETANOL KULIT KAYU MANIS DALAM MENURUNKAN AKUMULASI PLAK GIGI
}

\author{
Syahdiana Waty*, Dwi Suryanto**, Yurnaliza** \\ *Poltekkes Kemenkes Medan, ** Departemen Biologi Fakultas Matematika dan Ilmu Pengetahuan Alam Universitas \\ Sumatera Utara \\ Email : syahdianawaty@gmail.com
}

\begin{abstract}
Abstrak
Kulit kayu manis merupakan salah satu obat tradisional yang diduga mengandung beberapa senyawa antibakteri seperti flavonoid, saponin dan cinnamaldehid yang dapat menghambat pertumbuhan bakteri di rongga mulut. Efek ekstrak kulit kayu manis secara in vitro terhadap bakteri di rongga mulut telah sering dilakukan namun pengaruhnya sebagai obat kumur dalam menurunkan indeks plak gigi perlu dikaji. Penelitian ini bertujuan untuk mengetahui efektivitas berkumur dengan larutan ekstrak etanol kulit kayu manis dalam menurunkan akumulasi plak gigi. Kulit kayu manis diekstrak secara maserasi dengan etanol $80 \%$. Obat kumur kulit kayu manis dibuat pada konsentrasi $6.25 \%$. Sampel dalam penelitian ini merupakan responden yang berkunjung di klinik Drg. Syahdiana Waty, Medan, Sumatera Utara. Pengukuran indeks plak gigi dilakukan dua kali yaitu sebelum berkumur dan sesudah berkumur dengan larutan ekstrak etanol kulit kayu manis. Analisis data yang digunakan adalah uji Wilcoxon untuk mengetahui perbedaan yang signifikan antara indeks plak gigi sebelum berkumur dan sesudah berkumur dengan larutan ekstrak etanol kulit kayu manis. Hasilnya menunjukkan bahwa ekstrak etanol kulit kayu manis mengandung senyawa metabolit sekunder golongan alkaloida, flavonoid, saponin dan glikosida. Perbedaan indeks plak gigi yang signifikan antara sebelum dan sesudah berkumur dengan larutan ekstrak etanol kulit kayu manis 0.000 $(<0.05)$. Berdasarkan hasil penelitian ini dapat disimpulkan bahwa larutan ekstrak etanol kulit kayu manis efektif menurunkan akumulasi plak gigi.
\end{abstract}

Kata kunci : kulit kayu manis, indeks plak gigi, obat kumur

\section{PENDAHULUAN}

Kulit kayu manis (Cinnamomum burmanni) merupakan salah satu tanaman rempah obat tradisional yang murah dan mudah didapat namun masih belum dimanfaatkan secara maksimal. Kulit kayu manis dan daunnya memiliki kandungan minyak atsiri, saponin dan flavonoid yang sudah banyak digunakan sebagai tanaman herbal yang berkhasiat untuk berbagai penyakit (Pitojo et al., 2016). Kandungan terbesar dari kulit kulit kayu manis adalah minyak atsiri yang mempunyai kandungan utama senyawa sinamaldehid (60.72\%), eugenol (17.62\%) dan kumarin (13.39\%). Kandungan tersebut memiliki potensi sebagai antibakteri (Puspita et al., 2013).

Penyakit gigi dan mulut di Indonesia prevalensinya terus meningkat, dan yang paling tinggi adalah karies. Terjadinya karies dan kelainan jaringan penyangga gigi diawali dengan terbentuknya plak gigi (Pratiwi, 2005). Terbentuknya plak yang berupa lapisan tipis yang menempel pada permukaan gigi dan terkadang juga ditemukan pada gusi dan lidah adalah disebabkan oleh sisa-sisa makanan yang diuraikan oleh bakteri-bakteri patogen yang ada di rongga mulut (Chandraban et al., 2012).

Berbagai cara dan metode untuk mengurangi akumulasi plak di dalam rongga mulut telah banyak dilakukan, antara lain dengan menyikat gigi dengan teratur, berkumur dengan larutan antiseptik, membersihkan interdental dengan dental floss, membersihkan lidah, mengunyah permen karet, dan menghindari makanan yang manis (Ladytama et al., 2014). Cara yang paling mudah untuk menghilangkan plak adalah dengan berkumur. Beberapa penelitian telah menunjukkan efektivitas dan kegunaan obat kumur antiseptik yang mengandung bahan aktif seperti chlorhexidine dan minyak esensial untuk mencegah dan mengontrol pembentukan plak dan radang gusi (Endarti et al., 2006).

Pada penelitian Puspita et al., (2013) diketahui bahwa ekstrak kulit kayu manis berpengaruh terhadap pertumbuhan Streptococcus mutans yang merupakan bakteri utama penyebab karies gigi, tetapi belum ada informasi tentang efektivitas penggunaan ekstrak kulit kayu manis tersebut sebagai obat kumur untuk mengurangi plak gigi. Berdasarkan latar belakang tersebut, maka peneliti tertarik untuk mengetahui efektivitas berkumur larutan ekstrak etanol kulit kayu manis dalam menurunkan akumulasi plak gigi. 


\section{BAHAN DAN METODE}

Penelitian ini merupakan penelitian eksperimental murni dengan rancangan one group pretest-postest. Penelitian ini dilaksanakan di laboratorium farmasi Universitas Sumatera Utara dan klinik Drg. Syahdiana Waty. Bahan-bahan yang digunakan terdiri dari kulit kayu manis dengan pelarut etanol dan aquades steril sebagai pelarut obat kumur. Besar sampel sebanyak 40 dan dihitung berdasarkan rumus Slovin yang merupakan responden yang berkunjung di Klinik Gigi Drg. Syahdiana Waty, Medan dan sesuai dengan kriteria inklusi.

Pembuatan ekstrak kulit kayu manis dilakukan dengan cara maserasi. Simplisia sebanyak $1 \mathrm{~kg}$ direndam ke dalam 10 L etanol $80 \%$ yang sudah didestilasi selama 7 hari. Maserat yang dihasilkan dievaporasi menggunakan rotary evaporator pada suhu $60^{\circ} \mathrm{C}$. Selanjutnya ekstrak dimasukkan ke dalam water bath untuk menghilangkan uap air yang tersisa dari rotary evaporator. Ekstrak kulit kayu manis tersebut selanjutnya dilakukan pengujian fitokimia yang meliputi alkaloid, glikosida, glikosida antrakuinon, saponin, tanin, flavonoid dan steroid/triterpenoid.

Sebelum berkumur dengan larutan ekstrak etanol kulit kayu manis, dilakukan pengukuran indeks plak pada bagian bukal gigi 16, 26, 36 dan 46 serta labial dari gigi 11 dan 31. Larutan obat kumur ekstrak etanol kulit kayu manis $6.56 \%$ diaplikasikan pada responden sebanyak 10 $\mathrm{ml}$ selama 30 detik kemudian diukur kembali indeks plak gigi setelah 30 menit. Pengolahan data pada penelitian ini menggunakan uji Wilcoxon.

\section{HASIL}

Maserasi dari 1000 gram simplisia kulit kayu manis menggunakan pelarut etanol $80 \%$ dihasilkan filtrat berwarna coklat sebanyak $8750 \mathrm{~mL}$. Setelah diuapkan dengan rotary evaporator diperoleh ekstrak kental sebanyak 335 gram atau sebesar $33.5 \%$ berwarna coklat kemerahan. Ekstrak ini akan digunakan sebagai larutan kumur.

Hasil uji fitokimia pada ekstrak etanol kayu manis menunjukkan bahwa ekstrak etanol kulit kayu manis mengandung senyawa metabolit sekunder golongan saponin, flavonoid, alkaloid dan glikosida sedangkan tanin, steroid dan antrakuinon tidak ditemukan ( Tabel 1).

Tabel 1. Hasil Uji Fitokimia Ekstrak Etanol Kulit Kayu Manis

\begin{tabular}{cc}
\hline Uji Fitokimia & $\begin{array}{c}\text { Hasil Skrining Positif } \\
(+) / \text { Negatif }(-)\end{array}$ \\
\hline Tanin & - \\
Steroid/ Triterpenoid & - \\
Saponin & + \\
Flavonoid & ++ \\
Alkaloid & ++ \\
Glikosida & +++ \\
Antrakuinon & - \\
\hline
\end{tabular}

Tabel 2. Distribusi frekuensi responden menurut jenis kelamin

\begin{tabular}{lcc}
\hline Jenis Kelamin & $\mathrm{N}$ & $\%$ \\
\hline Laki-laki & 13 & 32.5 \\
Perempuan & 27 & 67.5 \\
Total & 40 & 100 \\
\hline
\end{tabular}

Tabel 3. Distribusi indeks plak menurut kategori skor plak

\begin{tabular}{lcccc}
\hline $\begin{array}{l}\text { Kategori } \\
\text { plak }\end{array}$ & skor & \multicolumn{2}{c}{$\begin{array}{c}\text { Sebelum } \\
\text { berkumur }\end{array}$} & \multicolumn{2}{c}{$\begin{array}{c}\text { Sesudah } \\
\text { berkumur }\end{array}$} \\
& $\mathrm{n}$ & $\%$ & $\mathrm{n}$ & $\%$ \\
\hline Baik & 0 & 0 & 38 & 95 \\
Sedang & 8 & 20 & 2 & 5 \\
Buruk & 32 & 80 & 0 & 0 \\
Total & 40 & 100 & 40 & 100 \\
\hline
\end{tabular}

Tabel 4. Hasil analisis perbandingan indeks plak sebelum dan sesudah berkumur larutan ekstrak etanol kulit kayu manis

\begin{tabular}{lcc}
\hline & $\begin{array}{c}\text { Indeks plak gigi } \\
\text { Rerata } \pm \text { SD }\end{array}$ & P \\
& $2.146 \pm 0.302$ & 0.000 \\
Sebelum berkumur & $0.516 \pm 0.265$ & 0.000 \\
\hline
\end{tabular}

\section{PEMBAHASAN}

Kulit kayu manis yang diekstrak degan pelarut etanol menghasilkan ekstrak yang lebih banyak dalam penelitian ini. Penelitian Alusinsing et al. (2014) juga menggunakan pelarut etanol $80 \%$ dalam maserasi serbuk kayu manis sebanyak 300 gram dalam $1500 \mathrm{~mL}$ etanol. Filtrat yang dihasilkan sebanyak $900 \mathrm{~mL}$ dan ekstrak kental sebanyak 83.56 gram atau $27.8 \%$. Jika dibandingkan dengan penelitian Alusinsing et al. (2014), maka hasil ekstrak yang dihasilkan dalam penelitian ini jumlahnya lebih banyak.

Kulit kayu manis diduga memiliki senyawasenyawa metabolit sekunder yang dapat digunakan dalam pengobatan dan dapat dideteksi dengan skrining fitokimia. Penelitian Puspita et al. (2013), juga menemukan senyawa metabolit sekunder pada ekstrak kulit kayu manis diantaranya adalah transinamaldehid, polifenol, flavonoid, saponin dan tannin. Pada penelitian Awang et al. (2013) melaporkan bahwa minyak esensial kulit kayu manis juga mengandung cinnamaldehid yang berpotensi sebagai antimikroba. Begitu juga dengan penelitian Repi et al. (2016) yang menyatakan bahwa kulit kayu manis mengandung beberapa senyawa antibakteri seperti eugenol dan cinnamaldehid.

Perbandingan jumlah sampel yang berjenis kelamin laki-laki dengan sampel yang berjenis kelamin perempuan yaitu sebanyak 14 sampel, yang terdiri dari 27 sampel berjenis kelamin perempuan dan 13 berjenis kelamin lakilaki. Dari hasil penelitian diketahui indeks plak gigi sebelum berkumur $80 \%$ (32 sampel) termasuk dalam kategori buruk dan 20\% (8 sampel) termasuk dalam kategori sedang. Tidak ada sampel yang memiliki indeks plak dengan kategori baik. Hal ini disebabkan karena 
masih kurangnya kesadaran masyarakat untuk menjaga kesehatan gigi dan mulut (Sartika et al., 2015).

Hasil pemeriksaan indeks plak gigi setelah berkumur dengan larutan ekstrak etanol kulit kayu manis menunjukkan hasil indeks plak 95\% (38 sampel) termasuk kategori baik dan hanya 5\% (2 sampel) dengan kategori sedang. Hal ini menunjukkan bahwa berkumur dengan larutan ekstrak kulit kayu manis mampu menurunkan akumulasi plak.

Pada tabel 4 dapat dilihat bahwa indeks plak gigi berkurang secara signifikan $0.000 \quad(\mathrm{p}<0.05) \quad$ setelah berkumur dengan larutan ekstrak etanol kulit kayu manis. Hasil penelitian ini menunjukkan bahwa berkumur dengan larutan ekstrak etanol kulit kayu manis efektif dalam menurunkan akumulasi plak gigi. Hal ini disebabkan karena kandungan pada kulit kayu manis mengandung senyawa antibakteri diantaranya transinamaldehid, polifenol, flavonoid dan tannin (Tasia et al., 2014). Kemampuan antibakteri pada ekstrak kulit kayu manis mampu menghambat pertumbuhan Streptococcus mutans sebagai salah satu bakteri penyebab terbentuknya plak (Puspita et al., 2013). Berkumur merupakan upaya melepaskan sisa-sisa makanan yang menempel pada gigi. Menyikat gigi dan berkumur bertujuan untuk memelihara kebersihan dan kesehatan gigi dan mulut. Dalam hal ini berkumur dengan larutan ekstrak etanol kulit kayu manis dapat dipertimbangkan sebagai obat kumur yang aman dan dapat menurunkan akumulasi plak.

\section{KESIMPULAN}

Dari hasil penelitian dapat disimpulkan bahwa :

1. Ekstrak kulit kayu manis mengandung senyawa metabolit sekunder golongan alkaloid, flavonoid, saponin dan glikosida.

2. Obat kumur ekstrak etanol kulit kayu manis efektif secara signifikan 0.000 $(\mathrm{p}<0.05)$ dalam menurunkan akumulasi plak di rongga mulut.

\section{SARAN}

Berdasarkan hasil yang diperoleh oleh peneliti perlu dilakukan penelitian lebih lanjut mengenai pengaruh penggunaan obat kumur ini dalam jangka waktu yang lama, efek lain terhadap kesehatan gigi dan mulut serta efektivitas obat kumur ekstrak kulit kayu manis dibandingkan dengan obat kumur sintetik.

\section{DAFTAR PUSTAKA}

Alusinsing, G., Bodhi, W., dan Sudevi, S. 2014. Uji Efektivitas Kulit Batang Kayu Manis (Cinnamomum burmannii) terhadap Penurunan Kadar Gula Darah Tikus Putih Jantan Galur Wistar (Rattus norvegicus) yang Diinduksi Sukrosa. Pharmacon Jurnal Ilmiah Farmasi. 3(3) :275-278.

Awang, AFIB., Susanti, D., and Taher, M. 2013. Antimicrobial Activity and Synergic Effect of Cinnamomum burmanii's Essential Oil \& its Isolated Compound (Cinnamaldehyde).
International Conference on Chemical, Agricultural and Medical Sciences. 29-30.

Chandrabhan, D., Hemlata, R., Renu, B. and Pradeep. V. 2012. Isolation of Dental Caries Bacteria from Dental Plaque and Effect of Tooth Pastes on Acidogenic Bacteria. Open Journal of Medical Microbiology. 2. 65-69.

Endarti, Fauzia, dan Zuliana, E. 2006. Manfaat Berkumur dengan Larutan Siwak (Salvadora persica). Majalah Kedokteran Nusantara. 39(4) : 393-401.

Ladytama, SR., Nurhapsari, A., dan Baehaqi, M. 2014. Efektivitas Larutan Ekstrak Jeruk Nipis (Citrus Aurantifolia) Sebagai Obat kumur Terhadap Penurunan Indeks Plak Pada Remaja Usia 12-15 Tahun- Studi di SMP Nurul Islami, Mijen, Semarang. Odonto Dental Journal. 1 (1).

Notoatmodjo, S. 2002. Metodologi Penelitian Kesehatan. Rineka Cipta.

Pitojo, S., dan Zumiati. 2016. Tanaman Bumbu dan Pewarna Nabati, Edisi. VIII. CV. Aneka Ilmu, Semarang. 64-66.

Pratiwi, R. 2005. Perbedaan Daya Hambat terhadap Streptococcus mutans dari beberapa Pasta Gigi yang Mengandung Herbal. Majalah Kedokteran Gigi (Dental Journal). 38. 64-67.

Puspita, A., Kholifa, M., dan Rochmanita, N. 2013. Pengaruh Konsentrasi Ekstrak Kulit kayu manis (Cinnamomum burmanni) dalam Menurunkan Pertumbuhan Streptococcus mutans secara In Vitro. Fakultas Kedokteran Gigi UMS.

Repi, NB., Mambo, C., dan Wuisan, J. 2016. Uji Efek Antibakteri Ekstrak Kulit Kayu Manis (Cinnamomum burmannii) terhadap Escherechia coli dan Streptococcus pyogenes. Jurnal eBiomedik (eBm). 4(1) : 1-5.

Sartika, S., Kawengian, S.E.S., and Mariati NW. 2015. Efektivitas Berkumur dengan Air Seduh Teh Hijau dalam Menurunkan Akumulasi Plak. Jurnal e-Gigi (eG).3(2) : 426-431.

Tasia, WRN., dan Widyaningsih, TD. 2014. Jurnal Review : Potensi Cincau Hitam (Mesona palustris BI.), Daun Pandan (Pandanus amaryllifolius) dan Kulit kayu manis (Cinamomum burmanii) Sebagai Bahan Baku Minuman Herbal Fungsional. Jurnal Pangan dan Agroindustri $.2(4): 128-136$. 